\title{
Measurement of Classroom Acoustic Parameters in the Public Schools of Medellin
}

\author{
Juan R. Aguilar \\ Grupo de Investigación en Modelamiento y Simulación Computacional Universidad de San Buenaventura- \\ Seccional Medellin, Carrera 56C \#51-110, Medellin, Colombia.

\begin{abstract}
Luz M. Tilano
Grupo de Investigación en Estudios Clínicos y Sociales en Psicología Universidad de San BuenaventuraSeccional Medellin, Carrera 56C \#51-110, Medellin, Colombia.
\end{abstract}

(Received 12 October 2015; accepted 26 April 2017)

Given the importance of classroom acoustics in the academic performance of school grade students, this research aims to assess the acoustical performance of a number of primary and secondary grade classrooms in public schools in Medellin, Colombia. Standardized measurements of classroom noise and reverberation time were taken in 26 classrooms located in seven public schools. The results revealed excessive noise and reverberation problems in all the classrooms assessed. The cause of this poor acoustical performance seems to be an inappropriate architectural design that prioritizes natural ventilation over classroom sound insulation and the lack of sound absorption materials to control classroom reverberation.

\section{NOMENCLATURE}

\begin{tabular}{|c|c|}
\hline ANSI & American National Standards Institute \\
\hline ASHA & $\begin{array}{l}\text { American Speech-Language-Hearing } \\
\text { Association }\end{array}$ \\
\hline BB93 & $\begin{array}{l}\text { Building Bulletin } 93 \text { Acoustic design of } \\
\text { schools: performance standards }\end{array}$ \\
\hline$L_{A e q, T}$ & $\begin{array}{l}\text { A-weighted equivalent continuous sound } \\
\text { pressure level measured over a period } T\end{array}$ \\
\hline$L_{M A X}$ & Maximum sound pressure level \\
\hline NTC & Colombian National Standards Institute \\
\hline$R T_{m i d}$ & $\begin{array}{l}\text { Average of reverberation time measured } \\
\text { at } 500 \mathrm{~Hz}, 1 \mathrm{kHz} \text { and } 2 \mathrm{kHz}\end{array}$ \\
\hline$T 60$ & $\begin{array}{l}\text { Reverberation time measured in accordance } \\
\text { to ISO 3382-2 }\end{array}$ \\
\hline WHO & World Health Organization \\
\hline
\end{tabular}

\section{INTRODUCTION}

Medellin is the second largest city in Colombia, with a population of 2.4 million inhabitants and a surface of approximately $381 \mathrm{~km}^{2}$. Its economy represents about $8 \%$ of the gross domestic product of the country and is also the second most industrialized city in Colombia. Medellin is regarded as the cultural capital of the country and won the 'Innovative City of the Year 2012' award. ${ }^{1}$ Education has been a priority for the Medellin government, which, since 2004, has implemented the "Medellin la màs Educada"-Medellin the most Educatedproject, aimed at the execution of diverse public policies for the strengthening of public education. In this context, the local government invested more than US \$140 million in infrastructure for educational facilities between 2004 and 2007. Due to this, about 45 major construction works and the refurbishment of several public schools have taken place. ${ }^{2}$

Climatologically speaking, Medellin has a humid subtropical climate with year-average temperatures ranging from 13.1 to $31.8^{\circ} \mathrm{C}$, an average relative humidity of $68 \%$, and an average of 224 rainy days with $1,656 \mathrm{~mm}$ of rainfall per annum, with mean wind velocities of between 1.4 and $2.6 \mathrm{~ms}^{-1}$ throughout the year. The city is also one of the noisiest in Colombia; during the day, environmental noise levels range from 69.0 to $77.0 \mathrm{~dB}(\mathrm{~A})$, with an average of $71.1 \mathrm{~dB}(\mathrm{~A})$. The main source of environmental noise comes from traffic, characterized by a large number of motorbikes and old public transportation buses. $^{3}$

When designing learning spaces for tropical climate conditions, architects face problems with classroom ventilation and sensible cooling. Natural ventilation emerges as a costeffective solution to these problems, as it has very low maintenance costs. Naturally ventilated classrooms produce airflows by means of ventilation openings through the classroom walls and façade. Nevertheless, these openings make classroom susceptible to the influence of external noise sources. Unless acoustical considerations are accounted for in the planning and design of schools, there is a potential risk of naturally ventilated classrooms having a poor acoustical performance, particularly in terms of noise levels and speech intelligibility.

Poor classroom acoustics have proven detrimental effects on the academic performance of students. The auditory system of children is not completely developed until late adolescence, so the skills required to process complex hearing tasks may remain not fully developed until the the age of twenty. ${ }^{4,5}$ Several studies have shown that primary and secondary grade children that attend classrooms with elevated noise levels exhibit poor academic performance, both in the short and longterm. ${ }^{6-9}$ Chronic exposure to classroom noise also affects sustained and visual attention, reduces speech perception, affects memory for processing semantic material, diminishes reading ability, decreases performance on standardized tests, ${ }^{10}$ and reduces reading comprehension ${ }^{11-15}$ skills. High classroom noise levels could also have a negative effect on long-term cognitive development, as academic performance in noisy schools is inversely proportional to noise exposure time. ${ }^{16,17}$

When reviewing the research on classroom acoustics in Colombia, we found that two previous studies had been conducted to assess the acoustical performance of university grade 
classrooms. The first was conducted in 2007 and involved measuring the noise level of 123 classrooms at the National University campus in Medellin. ${ }^{18}$ The second study was performed in 2009 and consisted of measuring the reverberation time in a total of 25 classrooms at the National University campus in Bogota. ${ }^{19}$ Although these surveys are incomplete characterizations of classroom acoustics, the excessive noise and reverberation time found evidenced a problem of inadequate classroom design.

Since classroom acoustics is of major importance to the academic performance and cognitive development of earlier grade students, this research aims to assess the acoustical performance of a number of primary and secondary grade classrooms. Between August 2012 and July 2013, we conducted a survey of standardized measurements of classroom noise and reverberation times in about 26 classrooms in 7 different public schools in Medellin. This article describes the procedures and findings of the classroom acoustics survey. In addition, we present a brief comparison of Colombian and international standards for classroom acoustics, and include a short review of design recommendations for naturally ventilated classrooms. This research does not attempt to examine how classroom acoustics affects the academic performance of Colombian students.

\section{SURVEY OF CLASSROOM ACOUSTIC PARAMETERS}

\subsection{Description of the Test Sample}

The test sample comprised a total of 32 different classrooms distributed in seven educational establishments. These schools enroll students from preschool to secondary school and represent a population of about 7,739 students from preschool to eleventh grade, and about 247 teachers. Some of these schools were built or refurbished between 2004 and 2007, as part of the previously mentioned public education project. Acoustical parameters were measured in a range of three to six classrooms per school, and the selection criteria were that the classrooms should have different architectural designs, i.e., different shapes and volumes, and be located on all floors of the buildings.

Two classrooms design types were identified: Type I corresponds to new classrooms in schools constructed or restored during the last five years. This classroom design is an enclosed plan, naturally ventilated using windows, linear grilles, and very large wall openings or perforated walls, as shown in the pictures of Figs. 1a, 1b, and 1c. These classrooms are made of brick or concrete block walls, concrete floor slabs, and concrete or gypsum board ceilings. No sound absorption materials for the control of room reverberation were observed. Type II classrooms correspond to those of unrestored, old schools. This second type of classroom is an enclosed plan, naturally ventilated using windows, small wall openings and louvres, as shown in Figure 1d. The building materials used are painted brick walls, tile floors, and wood or concrete ceilings. No sound absorption materials for the control of room reverberation were observed. Furthermore, a recurrent issue with these older classrooms was a noticeable lack of maintenance, as they presented broken window panes and access doors that could not be fully closed.
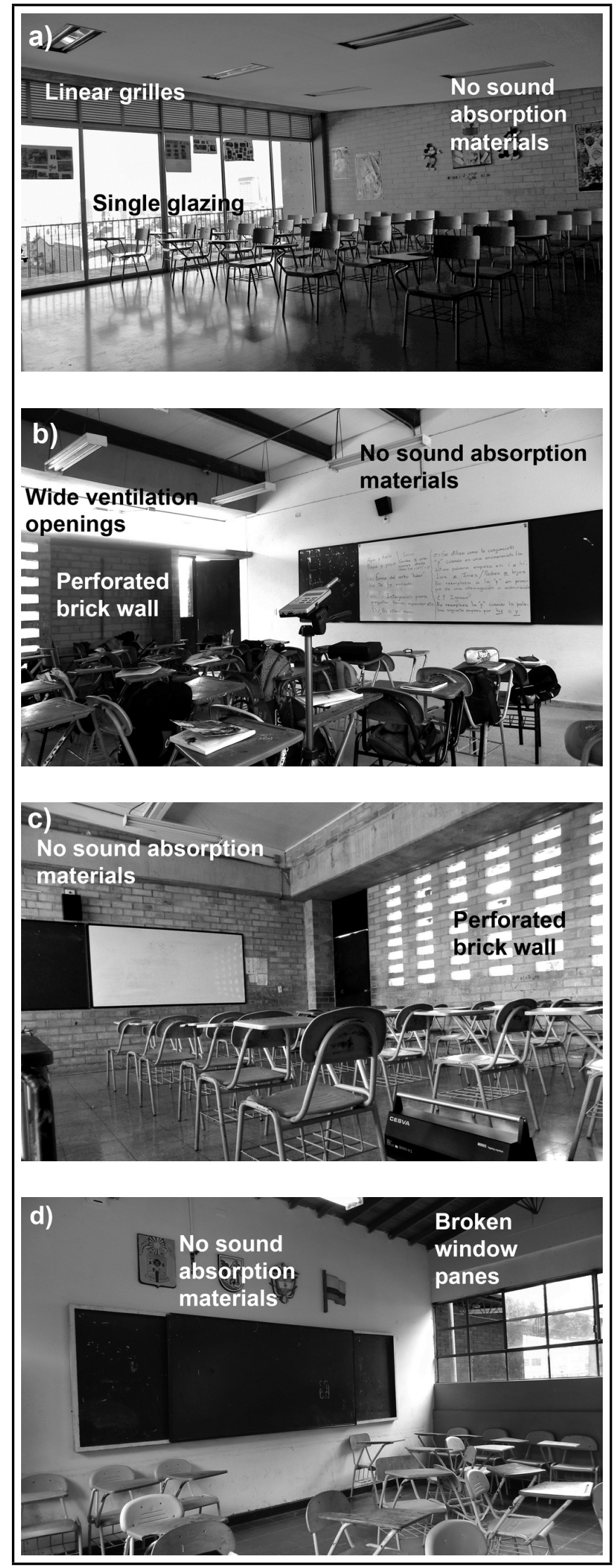

Figure 1. Pictures of actual Type I and Type II classrooms. a), b), c) Type I classrooms: New or refurbished, naturally ventilated using façade windows, linear grilles, very wide ventilation openings, and perforated brick walls. No sound absorption materials for controlling reverberation. d) Type II classroom: Older and unrestored, naturally ventilated using windows and smaller ventilation opening or small louvres. No sound absorption materials. 


\subsection{Acoustical Measurements Criteria}

Among the most recognized criteria for classrooms acoustics are ANSI S12.60, the ASHA 2005 Position Statement and BB93. ${ }^{20-22}$ Acoustical performance criteria for unoccupied school-grade classrooms are established in terms of the spatial average of A-weighted ambient noise sound pressure levels $L_{A e q}$ and the mid-frequency reverberation times $R T_{m i d}$. Classroom acoustic criteria in Colombia are given in NTC 4595:2006 and, as usual, acoustical performance is characterizein terms of noise level and reverberation time. ${ }^{23,24}$ Table 1 summarizes the noise and reverberation criteria in Colombian and international standards. Further comparisons between classroom acoustic standards can be found in literature. ${ }^{25}$ The measurement of classroom noise levels and reverberation times constitutes an effective method to characterize the acoustical performance of a classroom, and is consistently regarded as the main descriptor of classroom acoustics in international standards.

In this context, and in compliance with the procedures described in ANSI S12.60 and BB93, this research consisted of measuring the spatial average of classroom noise level $L_{A e q}$ and the reverberation time $R T_{\text {mid }}$. The measurements were performed in furnished but unoccupied classrooms with access doors and façade windows fully closed.

Unlike the procedures described in ANSI S12.60 and BB93, we assessed classroom noise during times of normal school operation on typical class days with regular student attendance and activities. Therefore, it is expected that school-generated noise may contribute to overall classroom noise. For example, this decision was justified by the limitations inherent to performing the measurements in empty schools during week days and under the premise that measuring noise on weekends or holidays would not be fully representative of a typical environmental noise situation. Also, we consider that disregarding school-generated noise could underestimate actual classroom noise levels, as naturally ventilated classrooms could also be susceptible to school-generated noise. Given these availabilities of classrooms to perform the noise measurement, only 30 classrooms were assessed.

Reverberation time measurements were taken in accordance with ISO 3382-2. ${ }^{26}$ To obtain suitably low background noise levels, measurements were performed on Saturday mornings when no students were at school. One school could not be accessed this day, so no reverberation time measurements were taken in this establishment and reverberation time was measured only in 28 classrooms.

\subsection{Classroom Noise Measurements}

To measure the noise level in a classroom, all students were relocated to a distant room within the school to avoid noise interferences. Once the classroom was unoccupied, the spatial average of A-weighted ambient noise sound pressure levels $L_{A e q}$ were obtained through three consecutive 10-minute measurements, to complete an overall duration of 30 minutes per classroom, in accordance with BB93. Figure 2 describes the typical measurement locations and setup used during classroom ambient sound pressure level assessments. Measurements of $L_{A e q, 10 \min }$ were taken at three different locations, $\mathrm{m} 1$ to $\mathrm{m} 3$, and the logarithmic average $L_{A e q, 30 \mathrm{~min}}$ was obtained for each classroom using Eq (1), $T_{e}=30$ minutes and

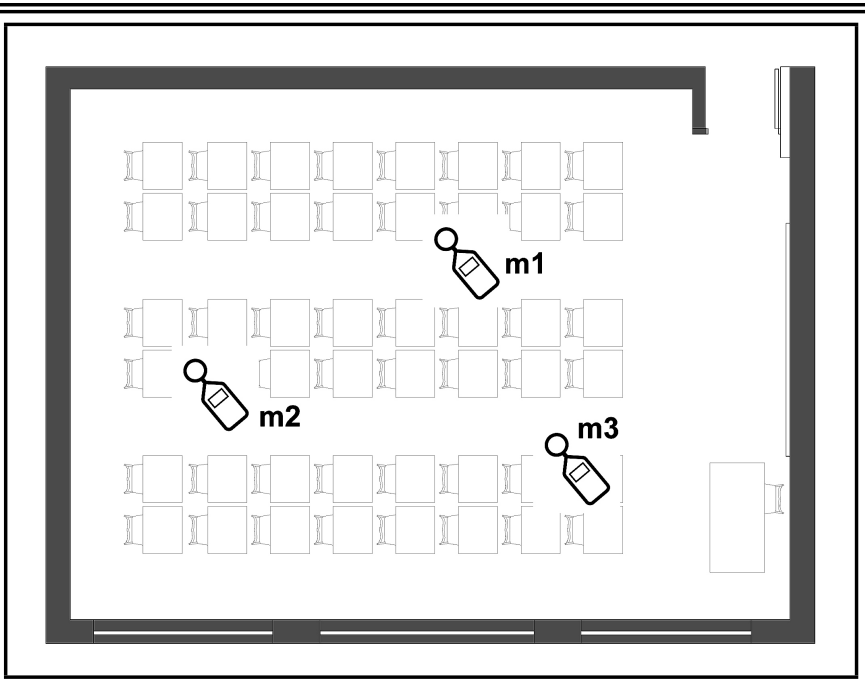

Figure 2. Typical measurement locations used during classroom ambient sound pressure level assessments.

$T_{i}=10$ minutes:

$L_{A e q, T_{e}}=10 \log _{10}\left[\frac{1}{T_{e}} \sum_{i=1}^{n}\left(T_{i} \times 10^{L_{A e q, T_{i}} / 10}\right)\right] \quad \mathrm{dB}(\mathrm{A}) ;$

Microphone locations were selected to avoid reflecting walls and furniture. Microphone separation distances of at least $2 \mathrm{~m}$ larger than the typical critical distance of the room-were used. All measurements were realized using Cesva SC310 and 01dB Solo Blue, Class 1 sound level meters. An instrument calibration field check was performed prior to each measurement.

\subsection{Reverberation Time Measurements}

Measurements were performed using the reverse-time integrated impulse response method, with exploding balloons as a sound source. In an effort to ensure repeatability, a twomicrophone arrangement was used to simultaneously capture the reverberant sound field at two different locations in each measurement. Similarly, balloons of the same type and inflated up to the same size were burst in each measurement. Figure 3 describes the typical source-microphone locations and setup employed in these measurements. The first microphone signal was obtained from the AC output of a Cesva SC301 sound level meter in order to take advantage of the better quality of its microphone; the second microphone signal corresponds to a dbx RTA-M low-cost microphone. Both signals were connected through an M-Audio USB audio interface to a laptop computer running Dirac 2.6 software. Depending on classroom volume, two or three reverberation time measurements were taken using 2 different source locations and 4 or 6 receiver locations, respectively, which meets the engineering level accuracy as stated in ISO 3382-2.

Classroom reverberation time was measured in octave bands from $125 \mathrm{~Hz}$ to $8 \mathrm{kHz}$. In order to provide a single-number description of classroom reverberation time, RTmid values were computed by averaging the reverberation times measured at $500 \mathrm{~Hz}, 1 \mathrm{kHz}$ and $2 \mathrm{kHz}$, in accordance with to BB93 criterion:

$$
R T_{m i d}=\frac{1}{3}\left(T 60_{500 \mathrm{~Hz}}+T 60_{1 \mathrm{kHz}}+T 60_{2 \mathrm{kHz}}\right)
$$

Finally, the spatial average of 4 or $6 R T_{m i d}$ values was computed to obtain the reverberation time for each classroom. 
Table 1. Comparison of classroom acoustic criteria between NTC 4595 and other international standards.

\begin{tabular}{||c|c|c|c||}
\hline Country & Standard & $\begin{array}{c}\text { Noise Criterion } \\
{[\mathrm{dB}(\mathrm{A})]}\end{array}$ & $\begin{array}{c}\text { Reverberation Time Criterion } \\
{[\mathrm{s}]}\end{array}$ \\
\hline Colombia & NTC $4595^{23}$ & 40 to $45^{\mathrm{a}}$ & $0.9-1.0$ \\
\hline USA & ANSI S12.60 20 & $\begin{array}{c}35\left(\mathrm{~V} \leq 566 \mathrm{~m}^{3}\right)^{\mathrm{b}} \\
55\left(\mathrm{~V}>566 \mathrm{~m}^{3}\right)\end{array}$ & $\begin{array}{c}0.6\left(\mathrm{~V} \leq 283 \mathrm{~m}^{3}\right)^{\mathrm{c}} \\
0.7\left(\mathrm{~V}>283 \mathrm{~m}^{3}\right)\end{array}$ \\
\hline USA & ASHA $^{21}$ & $35^{\mathrm{b}}$ & $\begin{array}{c}0.6\left(\mathrm{~V}<10,000 \mathrm{ft}^{3}\right)^{\mathrm{c}} \\
\left(10,000 \mathrm{ft}^{3} \geq \mathrm{V} \geq 20,000 \mathrm{ft}^{3}\right)\end{array}$ \\
\hline UK & $\mathrm{BB}^{22}$ & $35 / 40^{\mathrm{b}, \mathrm{d}, \mathrm{e}}$ & $\begin{array}{c}\mathrm{RT}_{\text {mid }} \geq 0.6(\text { Primary }) \\
\mathrm{RT}_{\text {mid }} \geq 0.8(\text { Secondary })\end{array}$ \\
\hline Worldwide & $\mathrm{WHO}^{15}$ & $35^{\mathrm{a}}$ & 0.6 \\
\hline
\end{tabular}

a The standard does not specify the measurement conditions of classroom ambient sound pressure levels. The noise criterion is established as a range and not as a single value.

b Measured in furnished, unoccupied classrooms, access door and windows closed; includes noise from equipment/services; excludes school-generated noise.

${ }^{c}$ Maximum value of octave bands centered at $500 \mathrm{~Hz}, 1 \mathrm{kHz}$, and $2 \mathrm{kHz}$.

$\mathrm{d}$ Permits open windows in naturally ventilated classrooms.

e Noise criterion of $35 \mathrm{~dB}(\mathrm{~A})$ for new classrooms and of $40 \mathrm{~dB}(\mathrm{~A})$ for refurbished classrooms.

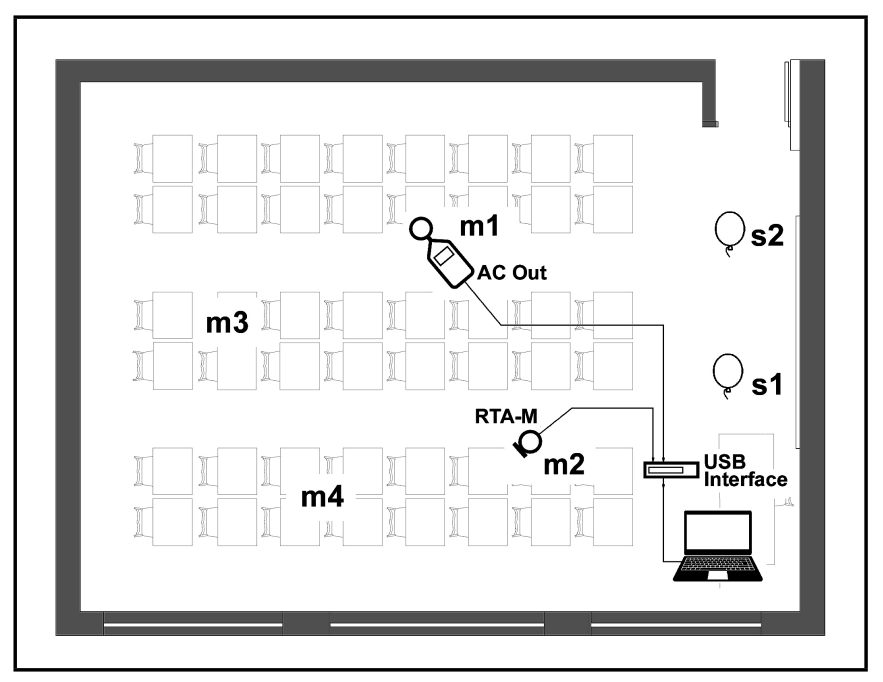

Figure 3. Typical measurement setup used during reverberation time measurements.

\section{RESULTS AND DISCUSSION}

\subsection{Survey Results}

\subsubsection{Classroom noise levels}

It was observed that classroom noise is comprised of schoolgenerated noise sources such as playground noise, corridor noise, and noise produced by teaching activities in adjacent classrooms, as well as of exterior sources outside the school, such as traffic and street vendors. The results of the spatially averaged $L_{A e q, 30 \text { min }}$ assessments of all the classrooms measured are summarized in Table 2. These show that all the classrooms are excessively noisy and largely exceed the ANSI S12.60, BB93 and NTC 4595 criteria. Classroom noise sound pressure level $L_{A e q, 30 m i n}$ varies from 55.7 to $72.0 \mathrm{~dB}(\mathrm{~A})$ with an average of about $64.6 \mathrm{~dB}(\mathrm{~A})$ (sound pressure average). Note the average level of $64.6 \mathrm{~dB}(\mathrm{~A})$ exceeds in $29.6 \mathrm{~dB}(\mathrm{~A})$ the limit recommended by international standards. The results also show that $56.7 \%$ of classrooms were in the $60.0-64.9 \mathrm{~dB}(\mathrm{~A})$ range, while $26.7 \%$ were in the $65.0-69.9 \mathrm{~dB}(\mathrm{~A})$ interval. Maximum sound pressure level values $L_{M A X}$ were also registered during the observation periods. These vary from 66.3 to $79.8 \mathrm{~dB}(\mathrm{~A})$, with an average of about $74.6 \mathrm{~dB}(\mathrm{~A})$.

\subsubsection{Reverberation times}

The results show that all classrooms are excessively reverberant, as was expected due to the lack of sound absorption
Table 2. Summary of measured classroom acoustic parameters: spatiallyaveraged classroom ambient noise sound pressure levels and mid-frequency reverberation times.

\begin{tabular}{|c|c|c|c|c|c|}
\hline $\begin{array}{c}\text { School } \\
\#\end{array}$ & $\begin{array}{c}\text { Classroom } \\
\#\end{array}$ & Type & $\begin{array}{c}L_{A e q, 30 m i n} \\
{[\mathrm{~dB}(\mathrm{~A})]}\end{array}$ & $\begin{array}{c}L_{M A X, s} \\
{[\mathrm{~dB}(\mathrm{~A})]}\end{array}$ & $\begin{array}{c}R T_{\text {mid }} \\
{[\mathrm{s}]}\end{array}$ \\
\hline \multirow{4}{*}{1} & 1 & I & 63.7 & 77.9 & 1.75 \\
\hline & 2 & I & 71.8 & 76.1 & 1.77 \\
\hline & 3 & I & 72.0 & 73.5 & 1.45 \\
\hline & 4 & I & 65.0 & 77.0 & 1.64 \\
\hline \multirow{6}{*}{2} & 1 & I & 61.3 & 75.4 & 1.29 \\
\hline & 2 & I & 61.1 & 73.3 & 1.35 \\
\hline & 3 & I & 62.1 & 69.3 & 1.60 \\
\hline & 4 & I & 63.9 & 70.4 & 1.68 \\
\hline & 5 & I & 62.3 & 71.8 & 1.41 \\
\hline & 6 & I & - & - & 1.57 \\
\hline \multirow{4}{*}{3} & 1 & I & 62.1 & 75.5 & 1.36 \\
\hline & 2 & I & 57.4 & 70.4 & 1.31 \\
\hline & 3 & I & 64.4 & 73.7 & 1.29 \\
\hline & 4 & I & 67.5 & 75.5 & 0.95 \\
\hline \multirow{5}{*}{4} & 1 & II & 64.4 & 72.8 & 1.60 \\
\hline & 2 & I & 64.6 & 75.1 & 2.16 \\
\hline & 3 & I & 69.7 & 77.6 & 1.75 \\
\hline & 4 & I & 65.9 & 71.9 & 1.44 \\
\hline & 5 & I & 66.3 & 73.7 & 2.31 \\
\hline \multirow{4}{*}{5} & 1 & I & 67.5 & 75.8 & - \\
\hline & 2 & I & 60.2 & 66.3 & - \\
\hline & 3 & I & 67.7 & 73.2 & - \\
\hline & 4 & I & 56.0 & 66.1 & - \\
\hline \multirow{5}{*}{6} & 1 & II & 61.0 & 76.2 & 1.11 \\
\hline & 2 & II & 62.2 & 78.5 & 1.35 \\
\hline & 3 & II & 64.1 & 76.9 & 1.25 \\
\hline & 4 & II & 64.1 & 70.8 & 1.16 \\
\hline & 5 & II & 65.3 & 74.0 & 1.02 \\
\hline \multirow{4}{*}{7} & 1 & I & 61.1 & 78.1 & 1.21 \\
\hline & 2 & I & 62.1 & 79.8 & 1.73 \\
\hline & 3 & I & 55.7 & 72.9 & 2.17 \\
\hline & 4 & I & - & - & 1.54 \\
\hline
\end{tabular}

materials. A summary of the spatially averaged $R T_{\text {mid }}$ per classroom is also shown in Table 2. Mid-frequency reverberation time RTmid ranges from 0.95 to $2.31 \mathrm{~s}$, with an average $R T_{m} i d$ of $1.51 \mathrm{~s}$ and $46.4 \%$ of classrooms having an $R T_{\text {mid }}$ above the mean. None of the classrooms measured comply with ANSI S12.60, BB93, NTC 4595, or any reverberation criterion.

\subsection{Discussion}

\subsubsection{Causes of poor classroom acoustics}

While most of the schools assessed are located in residential areas, where moderate environmental noise levels were observed, a number of institutions are located in urban areas with highly trafficked streets and nearby airports. Therefore, the 
environmental noise present in the school surroundings would not fully explain the high levels of classroom noise consistently observed in all schools. In contrast, the poor sound insulation of classroom walls and façades emerges as the major cause of classroom noise problems, as it allows the transmission of environmental and school-generated noise into the classrooms.

In schools built in the past five years, the excessive classroom noise levels are attributable to inadequate classroom design, which prioritizes natural ventilation over sound insulation. In older schools, classroom noise levels are explained by poor classroom maintenance issues such as broken windows panes, but also by the use of smaller ventilation openings. Furthermore, the lack of sound absorption materials observed in all the classrooms assessed produces excessive reverberation, which further increases ambient noise and degrades speech intelligibility.

Ultimately, these two acoustical defects-the very low sound insulation of classroom walls and façades and the absence of sound absorption materials to control reverberationwould explain the high levels of classroom noise and, in general, the poor acoustical performance of the classrooms assessed.

\subsubsection{Implications on academic performance}

According to literature, the typical classroom noise levels in Medellin public schools would cause the students' ability to concentrate to be reduced by $50 \%$ and cause about $25 \%$ of students to feel a high degree of annoyance. ${ }^{14}$ Furthermore, given the current levels of reverberation, it could be expected that only about $60 \%$ of the discourse pronounced by the teacher would be appropriately heard by the students. ${ }^{27}$

Likewise, the literature also suggests that high levels of classroom noise and long reverberation times, as measured in the public schools of Medellin, may contribute to the poor academic performance of students. Since reading comprehension skills of Colombian students are among the worst evaluated, ${ }^{28,29}$ some progress in this regard could be facilitated by improving the acoustical performance of classrooms in their schools.

\subsubsection{Recommendations for the acoustical design of naturally ventilated classrooms}

In designing naturally ventilated classrooms, architects must consider the sound insulation requirements of walls and façades and avoid the use of large openings, such as perforated brick walls, large louvres, and linear grilles. However, if these openings are indispensable, they should be indirect, i.e., not pass directly through the classroom walls or façade. There are several acoustical devices, such as silencers, double or triple louvre arrays, or lined duct inlets, that could be used as noise control solutions for natural ventilation openings. ${ }^{30}$ A design guideline for naturally ventilated classrooms is contained in BB93, and there are methods to estimate the natural ventilation potential from building exposure to environmental noise. ${ }^{30-32}$ Finally, sound absorption materials should be used to control classroom reverberation, which, in turn, would reduce the overall classroom noise and enhance speech intelligibility. The required amount of sound absorption material would be directly proportional to the volume of the classroom, and it could be distributed along the classroom walls and ceiling.

\section{CONCLUSIONS}

This study was the first of its kind in Colombia, as it aimed to assess the acoustical performance of 26 primary and secondary grade classrooms in the public schools of Medellin. The results show that the classrooms assessed do not meet any of the acoustical performance criteria expected for teaching spaces. Both classroom noise level and reverberation time criteria are exceeded in all classrooms, and findings show classroom noise sound pressure levels of between 55.7 and $72.0 \mathrm{~dB}(\mathrm{~A})$ and reverberation times of between 0.95 and $2.31 \mathrm{~s}$.

The poor acoustical performance of Medellin public schools is attributable to inappropriate architectural design, in which classrooms are conceived for natural ventilation, disregarding sound insulation requirements. Currently, classroom walls and façades have very low sound insulation properties and do not insulate the classroom from school-generated noise or external noise sources. Further, classroom designs do not consider sound absorption materials for the control of reverberation. This causes excessive reverberation, which increases classroom noise and reduces speech intelligibility.

In Colombia, acoustical performance criteria for classrooms are given in NTC 4595, but this does not constitute a mandatory building regulation or directive. Therefore, architects are free to choose whether or not to meet acoustical performance criteria, resulting in classroom acoustics that are frequently ignored in the design of schools. By making the acoustical requirements for classrooms and schools in Colombia mandatory, some improvement in the academic performance of their students could be attained.

Future research documenting the acoustical conditions in Colombian schools is desirable. This should comprise a much larger sample size, include preschool grade classrooms, and should consider the measurement of other classroom acoustic parameters, such as speech intelligibility and signal to noise ratio. Investigations that directly relate classroom acoustics to the academic performance of Colombian students are also required, and should be conducted by a multidisciplinary team that includes educational psychologists.

\section{ACKNOWLEDGEMENTS}

The authors would like to thank the Secretaria de Educacion de Medellin and Deans for allowing access to the schools that were assessed. They would also like to thank the students of the Sound Engineering and Psychology programs at the Universidad de San Buenaventura Seccional Medellin for their valuable collaboration in this research.

\section{REFERENCES}

1 Wall Street Journal Magazine, Wall Street Journal, Medellin City of the Year, 2015.

2 Ciudades para un Futuro más Sostenible. Polìtica pública educativa: Medellìn la más educada (Medellìn, Colombia), (2010).

3 AMVA, Actualización del Mapa de Ruido de la Zona Urbana del Municipio de Medellìn, (2011).

4 Moore, D., Auditory development and the role of experience, British Medical Bulletin, 63 (1), 171-181, (2002). https://dx.doi.org/10.1093/bmb/63.1.171 
5 Hazan, V. and Barrett, S., The development of phonemic categorization in children aged 6-12. Journal of Phonetics, 28 (4), 377-396, (2000). https://dx.doi.org/10.1006/jpho.2000.0121

6 Allen, P., Brogan, N., Allan, C., Impact of classroom noise on reading and vocabulary skills in elementary school-aged children, J. Acoust. Soc. Am., 115 (5), 2371-2371, (2004). https://dx.doi.org/10.1121/1.4809284

7 Klatte, M. and Hellbrück, J., Effects of classroom acoustics on performance and wellbeing in elementary school children: A field study, Environment and Behavior, 42 (5), 659-692, (2010). https://dx.doi.org/10.1177/0013916509336813

8 Ali, S., Study effects of school noise on learning achievement and annoyance in Assiut city, Egypt, Applied Acoustics, 74 (4), 602-606, (2013). https://dx.doi.org/10.1016/j.apacoust.2012.10.011

9 Shield, B. and Dockrell, J., The effects of environmental and classroom noise on the academic attainments of primary school children, J. Acoust. Soc. Am., 123 (1), 133-44, (2008). https://dx.doi.org/10.1121/1.2812596

10 Shield, B. and Dockrell, J., The effects of noise on children at school: a review, J. Building Acoustics, 10 (2), 97-106, (2003). https://dx.doi.org/10.1260/135101003768965960

11 Lukas, J., DuPree, R., Swing, J., Effects of noise on academic achievement and classroom behavior, Office of Noise Control, Cal. Dept. of Health Services, FHWA/CA/DOHS-81/01 (1981).

12 Bronzaft A. and McCarthy, D., The effect of elevated train noise on reading ability, Environmental Behavior, 7 (4), 517-528, (1975). https://dx.doi.org/10.1177/001391657500700406

13 Ronsse, L. and Wang, L., Effects of noise from building mechanical systems on elementary student achievement, ASHRAE Transactions, 116 (2), 347-354, (2010).

14 Ronsse, L. and Wang, L., Relationships between unoccupied classroom acoustical conditions and elementary student achievement measured in eastern Nebraska, J. Acoust. Soc. Am., 133 (3), 1480-1495, (2013). https://dx.doi.org/10.1121/1.4789356

15 Berglund, B., Lindvall, T., Schwela, D., Guidelines for Community Noise. World Health Organization, pp. 32, (1999).

16 Estrada, C. and Méndez, I., Impacto del ruido ambiental en estudiantes de educación primaria de la ciudad de México. Revista Latinoamericana de Medicina Conductual, 1 (1), 57-68, (2010). https://dx.doi.org/10.5461/rlmc.v1.n1.07

17 Goines, L. and Hagler, L., Noise pollution: a modem plague, South Med J., 100 (3), 287-94, (2007). https://dx.doi.org/10.1097/SMJ.0b013e3180318be5

18 Universidad Nacional de Colombia Sede Medellin, Estudio de los Niveles de Ruido en las Aulas de Clase - Resumen de Datos de Prácticas de Estudiantes. Medellìn, (2007).
19 Cantor L. and Muñoz, A., Classroom acoustics conditions at public University in Bogotá, Med. Segur. Trab., 55 (216), 26-34, (2009).

20 ANSI S12.60-2010, Acoustical Performance Criteria, Design Requirements, and Guidelines for Schools. Part 1: Permanent Schools. New York, (2002).

21 American Speech-Language-Hearing Association, Acoustics in Educational Settings: Position Statement, (2005). https://dx.doi.org/10.1044/policy.PS2005-00028

22 Department for Education, Building Bulletin 93: Acoustic design of schools: performance standards, (2015).

23 NTC 4595 Ingenierìa Civil y Arquitectura - Planteamiento y Diseño de Instalaciones y Ambientes Escolares, Ministerio de Educación Nacional, (2006).

24 Anexo a la Norma NTC 4595: Comentarios sobre el tema de la comodidad auditiva, Ministerio de Educación Nacional de Colombia, (2006).

25 Vallet, M. and Karabiber, Z., Some European policies Regarding Acoustical Comfort in Educational Buildings. Noise Control Engineering Journal, 50 (2), 58-62, (2002). https://dx.doi.org/10.3397/1.2839678

26 International Organization for Standardization (ISO) Acoustics. Measurement of room acoustic parameters, part 2: Reverberation time in ordinary rooms. (Standard No. ISO 3382), Genve, Switzerland: ISO, (2012).

27 Levitt, H. and Webster, J., Effects of noise and reverberation on speech, Handbook of Acoustical Measurements and Noise Control, Chapter 16, edited by Cyril M. Harris. McGraw-Hill, (1991).

28 Online at: http://www.elpais.com.co/elpais/colombia /noticias/alumnos-en-colombia-leen-pero-entienden

29 Online at http://www.icfes.gov.co/investigacion/component /docman/doc_download/147-informe-de-resultados-decolombia-en-pirls-2011?Itemid=

30 De Salisa, M., Oldhama, D., and Sharplesb, S., Noise control strategies for naturally ventilated buildings, Building and Environment, 37 (5), 471-484, (2002). https://dx.doi.org/10.1016/S0360-1323(01)00047-6

31 Bibby, C. and Hodgson, M., Field measurement of the acoustical and airflow performance of interior natural-ventilation openings and silencers, Building and Environment, 67, 265-273, (2013). https://dx.doi.org/10.1016/j.buildenv.2013.05.025

32 Barclay. M. and Kang, J., Sharples, S., Combining noise mapping and ventilation performance for non-domestic buildings in an urban area, Building and Environment, 52, 68-76, (2012). https://dx.doi.org/10.1016/j.buildenv.2011.12.015 